\title{
Collaborative care models for integrating mental health and primary care
}

\section{A policy overview}

\author{
Rachelle Maskell, Anna Rudkovska, Marisa Kfrerer, Shannon Sibbald \\ Faculty Reviewer: Gerald McKinley, PhD (Pathology and Laboratory Medicine)
}

\section{ABSTRACT}

Background: Mental health service demands in Ontario often result in long wait times and a lack of access to specialized services. As a result, primary care providers are frequently required to provide mental health care for patients with complex diagnoses despite a lack of support or sufficient training. To address these issues, a shift toward collaborative models of mental health care delivery is occurring. Objective: This paper aims to assess whether evidence-based policy recommendations to improve collaborative mental health care are addressed in the recent Patients First documents. Methods: To achieve this, a qualitative analysis was conducted using NVivo10@( Results: While many of the evidence-based policy recommendations were mirrored in the Patients First documents, very few addressed collaborative mental health care directly. Implications: More research is required to fully understand the effects of the implementation of Patients First on mental health systems and services.

\section{INTRODUCTION}

In recent years, there has been an increased focus on the need to reorganize mental health care delivery in Ontario and Canada. This focus on restructuring arguably comes as a response to an increase in patient demand coupled with long wait times or inability to access psychiatric services. ${ }^{1}$ These circumstances place increased responsibilities on family physicians to treat complex mental health conditions. ${ }^{2}$ A lack of support for primary care providers to adequately and effectively treat mental health disorders sparked a shift toward collaborative models of care delivery. Such models of mental health care integrate mental health services and primary care through the utilization of existing infrastructures and resources. ${ }^{2}$ Through these models, different health care providers are connected in a health service network which allows them to share resources and expertise. Studies of these models have demonstrated increased patient and provider satisfaction as well as significant reductions in treatment delays and costs. ${ }^{3-5}$

\section{COLLABORATIVE CARE}

In 1997, a revolutionary position paper was developed by the Canadian Psychiatric Association and the College of Physicians of Canada on the topic of shared mental health care which generated wide-reaching interest and awareness. ${ }^{6}$ As a response to this paper, a working group was created to promote models of shared care which focused on encouraging coordination between family physicians and psychiatrists. ${ }^{6}$ However, in recent years much has changed including a shift from the focus on the physician/psychiatrist relationship to a push for collaboration between a wide range of experts including but not limited to providers of mental health services and primary care. ${ }^{7}$

Collaborative mental health care emerged in Canada with the goal to address the rising needs of Canadians with mental health concerns as it is now understood that 1 in 5 Canadians experience mental illness in their lifetime. ${ }^{8,9}$ The objective was to increase the capacity of primary care to address issues related to managing mental health and addictions. ${ }^{2}$ At its core, collaborative mental health care is a patient-centred approach which relies on different specialties, disciplines, or sectors working together to offer services and support to individuals in need. ${ }^{7}$ Collaborative mental health care also leverages personal connections, supporting the unique and changing needs of individuals, as well as catering care to cultural and personal preferences. The collaborative mental health model often draws on local resources, skills, and interests of the participating partners. While there is no single model, collaborative mental health care is often operationalized through the use of effective communication, consultation, coordination, co-location and/or integration of mental health and primary care providers into one care team. ${ }^{7}$ Between 2003 and 2007, the Canadian Collaborative Mental Health Initiative (CCMHI), supported by the Primary Health Care Transition Fund, embarked on improving and promoting collaborative mental health care across Canada. ${ }^{8}$ Today, however, the incidences of mental health and addictions are still very high, and the heavy reliance on primary care providers to support individuals living with complex mental illness remains despite the lack of resources and inadequate training.

In 2011, Kates et al published a revised position paper to update collaborative mental health literature on lessons learned through research, areas and opportunities for improvement, as well as action items for change. ${ }^{7}$ They suggested that there are many changes that can be made at the policy and practice level to encourage improvement of and access to high-quality collaborative mental health care. Including patients and their families in care planning as well as focusing on early detection of mental illness were among strategies proposed. ${ }^{7}$ Despite growing evidence showing that collaborative mental health care contributes to reduced wait times and costs and improves overall patient and provider satisfaction, it is 
not well-understood how these models have been incorporated into health policy. This issue, also known as the knowledge-to-practice gap, is a recognized problem in health research, as federal and provincial policies are often developed using insufficient evidence. ${ }^{10}$ This paper aims to provide a brief overview of the recent shift in Ontario health policy by assessing whether proposed policy changes adequately incorporate the current evidence and recommendations brought forth in Kates et al's 2011 position paper.

\section{PATIENTS FIRST}

The Patients First Act is a policy initiative initiated by the Ministry of Health and Long-Term Care (MOHLTC) to improve the province's health system. ${ }^{11}$ Outlined in four public documents, these proposed policy changes focus on four primary objectives: ${ }^{12-15}$

1) Provide faster access to correct care,

2) connect services by providing better coordination and integration closer to home,

3) support families and patients through education and transparency to allow for more informed decision making, and

4) protect the universal health system by focusing on value, quality and sustainability.

The structural changes included in the Patients First Act are an attempt to develop a more integrated health care system which emphasizes quality of care and the patient experience above all other factors. ${ }^{12-15}$

\section{METHODS}

The 4 documents outlining these changes were collated and compared to Kates et al's 'Across the System' and 'Provincial and (or) Territorial Governments and Regional Health Authorities' recommendations. ${ }^{7}$ NVivo 10, a qualitative analysis software, was used by the authors to assess whether the noted policy recommendations were addressed in the Patients First documents. The content of the documents was categorized using the twenty-three recommendations included by Kates et $a^{7}$ The qualitative analysis software provided a visual overview of whether recommendations were addressed in Patients First and to what degree.

\section{FINDINGS}

\section{'Across the System' Recommendations:}

The Patients First documents were coded using the twenty-three Kates et al recommendations and were measured by frequency of occurrence (Table 1 and Table 2). The frequencies at which the 'Across the System' recommendations were mirrored in the Patients First documents were quite varied with 6 of 10 recommendations appearing in the public documents (Table 1).12-15 The recommendation most frequently mirrored reflected a focus on quality improvement, access, and efficiency. To a lesser degree, the inclusion of individuals, families, and caregivers in project planning and evaluation was also included. For example, in the Patients First: Action Plan for Health Care document, families were often dis- cussed in planning and collaboration. ${ }^{12}$ Less frequently discussed recommendations include development of strategies to reduce stigma among providers, promotion of mental health and well-being as drivers for change, the use of technology for managing information and linking providers, and including individuals and families in their own care. Lastly, of the 10 Kates et al 'Across the System' recommendations reflected in the Patients First documents, only 2 directly addressed mental health care while several recommendations are not discussed at all.

Table 1. Across the system recommendations from Kates et al

\begin{tabular}{|c|c|c|}
\hline Kates et al. Across the System Recommendations & $\begin{array}{c}\text { Health } \\
\text { care as } \\
\text { a whole }\end{array}$ & $\begin{array}{c}\text { Specific to } \\
\text { Mental } \\
\text { Health }\end{array}$ \\
\hline $\begin{array}{l}\text { 1. Include individuals and their families and (or) } \\
\text { caregivers as partners in their own care. Ensure that } \\
\text { people with mental health problems have clear } \\
\text { treatment or wellness plans, developed in } \\
\text { partnership with the individual and based on their } \\
\text { own goals. A copy of these plans should be provided } \\
\text { to the individual. }\end{array}$ & $x$ & \\
\hline $\begin{array}{l}\text { 2. Include individuals and their families and (or) } \\
\text { caregivers in the planning and evaluation of } \\
\text { collaborative projects. To a large extent, the } \\
\text { development of new projects needs to be based on } \\
\text { what we can learn from the stories and journeys of } \\
\text { people with lived experience about where our } \\
\text { systems are failing them and how care could be } \\
\text { improved. }\end{array}$ & $x$ & \\
\hline $\begin{array}{l}\text { 3. Develop strategies that will reduce stigma and } \\
\text { discrimination among all health care providers, } \\
\text { including those that will lead to a better } \\
\text { understanding of cultural diversity }\end{array}$ & $x$ & \\
\hline $\begin{array}{l}\text { 4. Promote mental health, wellness, and recovery as } \\
\text { goals of system changes. }\end{array}$ & $x$ & $\mathrm{X}$ \\
\hline $\begin{array}{l}\text { 5. Focus on quality improvement, access, and efficiency } \\
\text { as drivers of system change. }\end{array}$ & $x$ & $x$ \\
\hline $\begin{array}{l}\text { 6. Define competencies for all health professionals } \\
\text { working in collaborative mental health partnerships. }\end{array}$ & & \\
\hline $\begin{array}{l}\text { 7. Ensure that respective roles and responsibilities of } \\
\text { all partners are clearly defined and understood. }\end{array}$ & & \\
\hline $\begin{array}{l}\text { 8. Strengthen personal contacts by organizing events, } \\
\text { such as joint clinical rounds, joint educational } \\
\text { rounds, practice observation, and formal continuing } \\
\text { professional development events, that bring } \\
\text { together MH\&A and primary care clinicians and staff }\end{array}$ & & \\
\hline $\begin{array}{l}\text { 9. Use new technologies for managing information, } \\
\text { including a common electronic medical record and } \\
\text { evidence-guided algorithms to enhance } \\
\text { collaboration and efficient data collection and } \\
\text { analysis; registries to support proactive, population- } \\
\text { based care; and telemedicine, which offers new } \\
\text { ways to link providers, enhance collaboration, and } \\
\text { provide consultation to underserved communities. }\end{array}$ & $x$ & \\
\hline $\begin{array}{l}\text { 10. Build networks of providers, information technology } \\
\text { experts, researchers, and consumers interested in } \\
\text { collaborative mental health care to enable } \\
\text { participants to exchange ideas, share experiences, } \\
\text { and work together to develop new projects. }\end{array}$ & & \\
\hline
\end{tabular}




\section{'Provincial and (or) Territorial Governments and Regional Health Authorities' Recommendations:}

Frequency of occurrence of provincial/territorial and regional health authorities' recommendations was greater and less varied across all documents. Overall, twelve of the thirteen recommendations in this category were present in the Patients First documents with 6 directly pertaining to mental health care. There appeared to be a focus on meeting the needs of marginalized populations, addressing health resource shortages, and the development of strategies to ensure individuals with mental health and addictions receive comprehensive primary care.

Table 2. Provincial, territorial governments, and regional health authorities recommendations from Kates et al

\begin{tabular}{|c|c|c|}
\hline $\begin{array}{c}\text { Kates et al. Provincial and (or) Territorial Governments and Regional } \\
\text { Health Authorities Recommendations }\end{array}$ & $\begin{array}{l}\text { Health } \\
\text { care as a } \\
\text { whole }\end{array}$ & $\begin{array}{l}\text { Specific to } \\
\text { mental } \\
\text { health }\end{array}$ \\
\hline \multicolumn{3}{|l|}{ 1. Give priority to collaborative projects that offer opportunities for; } \\
\hline $\begin{array}{l}\text { a. Early detection and intervention, and ongoing monitoring } \\
\text { of children and youth with mental health problems and } \\
\text { their families and (or) caregivers }\end{array}$ & $\mathrm{X}$ & $\mathrm{x}$ \\
\hline $\begin{array}{l}\text { b. Early detection and intervention, ongoing monitoring and } \\
\text { relapse prevention of seniors with mental health } \\
\text { problems and the needs of their caregivers }\end{array}$ & & \\
\hline $\begin{array}{l}\text { c. Meeting the needs of populations that may be } \\
\text { marginalized or have particular difficulty with access to } \\
\text { services, including Aboriginal populations, people who } \\
\text { are homeless, people from different cultures, and people } \\
\text { whose first language is neither English nor French }\end{array}$ & $\mathrm{x}$ & $\mathrm{x}$ \\
\hline $\begin{array}{l}\text { d. Community-based intervention for the integrated } \\
\text { management of crises }\end{array}$ & $\mathrm{x}$ & $\mathrm{x}$ \\
\hline $\begin{array}{l}\text { e. Access to interdisciplinary models of care when } \\
\text { individuals or their families identify the lack of these } \\
\text { services within their primary care services }\end{array}$ & $\mathrm{x}$ & \\
\hline $\begin{array}{l}\text { f. Addressing shortages of health resources, including those } \\
\text { created by geographic disparities }\end{array}$ & $\mathrm{x}$ & \\
\hline $\begin{array}{l}\text { g. Supporting collaborative education projects, especially } \\
\text { those that take place in the primary care setting }\end{array}$ & $\mathrm{x}$ & \\
\hline $\begin{array}{l}\text { h. Mentoring and email or telephone support of family } \\
\text { physicians by psychiatrists, as in the successful Ontario } \\
\text { Collaborative Mental Health Project, } 65 \text { which is now } \\
\text { being extended to other specialties }\end{array}$ & $\mathrm{x}$ & \\
\hline \multicolumn{3}{|l|}{$\begin{array}{l}\text { 2. Test demonstration projects that provide data on how } \\
\text { collaborative projects can help address common problems faced by } \\
\text { health care systems, including }\end{array}$} \\
\hline a. Meeting the needs of underserved populations & $x$ & \\
\hline b. Serving people in isolated communities & $x$ & \\
\hline c. Reducing waiting times and improving access to care & $x$ & $x$ \\
\hline $\begin{array}{l}\text { d. Improving physical health outcomes for people with } \\
\text { mental disorders }\end{array}$ & $\mathrm{x}$ & $x$ \\
\hline $\begin{array}{l}\text { Develop strategies to ensure that people with mental illnesses and } \\
\text { addictions have access to appropriate and comprehensive primary } \\
\text { health care, } 32 \text { including incorporating primary care clinicians } \\
\text { (nurses, nurse practitioners, physician assistants, and family } \\
\text { physicians) into mental health programs }\end{array}$ & $\mathrm{x}$ & $x$ \\
\hline
\end{tabular}

\section{DISCUSSION}

Of the twenty-three recommendations discussed in Kates et al, eighteen (78\%) were present in the Patients First documents; however, only 8 of the twenty-three recommendations (34\%) addressed mental health care directly. Despite the absence of directed guid- ance for mental health care reform, there is a great deal of thematic overlap between Kates et al's recommendations and the Patients First focus on patient-centredness, quality improvement and interdisciplinary collaboration. More research is required to see if these policy changes translate into improved collaborative mental health care.

\section{CONCLUSION}

While the Patients First documents demonstrate substantial thematic overlap with Kates et al's (2011) evidence-based policy recommendations, gaps remain as few directly address collaborative mental health care. However, it is possible that because there is considerable thematic overlap, these important policy changes will translate into improved mental health care. We support further research to understand the full affects of the practical implementation of Patients First policies on mental health systems and services.

\section{REFERENCES}

1. Swenson JR, Gillis K, Busing N, et al. Development and Implementation of a Collaborative Mental Health Care Program in a Primary Care Setting: The Ottawa Share Program. Can J Community Ment Heal. Fall 2008:27(2):75-91.

2. Mulvale G, Bourgeault IL. Finding the Right Mix: How Do Contextual Factors Affect Collaborative Mental Health Care in Ontario? [Internet] Can Public Policy. Jan 2007;33 [cited 2017 Oct 18]. Available from: http://utpjournals.metapress.com/index/H4000370L1P4K804.pdf

3. van Orden M, Hoffman T, Haffmans J, et al. Collaborative Mental Health Care Versus Care as Usual in a Primary Care Setting: A Randomized Controlled Trial. Psychiatr Serv. Jan 2009;60(1).

4. Woltmann E, Grogan-Kaylor A, et al. Comparative Effectiveness of Collaborative Chronic Care Models for Mental Health Conditions Across Primary, Specialty, and Behavioral Health Care Settings: Systematic Review and Meta-Analysis. Am J Psychiatry. Aug 2012;(18):790-804.

5. Durbin A, Durbin J, Hensel JM. Barriers and Enablers to Integrating Mental Health into Primary Care: A Policy Analysis. J Behav Health Serv Res. Jan 2016:127-139.

6. Kates N, Craven M, Bishop J, et al. Shared Mental Health Care in Canada. Can J Psychiatry. Oct 1997:42(8)

7. Kates N, Mazowita G, Lemire F, et al. The Evolution of Collaborative Mental Health Care in Canada : A Shared Vision for the Future. Can J Psychiatry. May 2011;56(5):1-10.

8. Macfarlane D. Current State of Collaborative Mental Health Care [Internet]. Mississauga (ON): Canadian Collaborative Mental Health Initiative; 2005 June [cited 2017 Oct 18]. Available from: http://www. shared-care.ca/files/12_OverviewPaper_EN.pdf.

9. Smetanin P, Stiff D, Adair C, et al. The life and economic impact of major mental illnesses in Canada: 2011 to 2041. RiskAnalytica, behalf Ment Heal Comm Canada 2011. Dec 2011;199.

10. Curran J, Grinshaw J, Hayden J, et al. Knowledge Translation Research: The Science of Moving Research Into Policy and Practice. J Contin Educ Health Prof. Sept 2011;31(3):174-180.

11. Bill 210, An Act to Amend Various Acts in the Interests of Patient-Centred Care, First Reading, June 2, 2016. Canada; 2016.

12. Ontario Ministry of Health and Long-Term Care. Patients First: Action Plan for Health Care. [Internet]; 2015 February. [cited 2017 Oct 18]. Available from: http://www.health.gov.on.ca/en/ms/ecfa/healthy_ change/.

13. Ontario Ministry of Health and Long-Term Care. Patients First: A Proposal to Strengthen Patient-Centred Health Care in Ontario. [Internet]; 2015 December. [cited 2017 Nov 6] Available from: http:// www.health.gov.on.ca/en/news/bulletin/2015/docs/discussion_paper_20151217.pdf.

14. Ontario Ministry of Health and Long-Term Care. Patients First: Reporting Back on the Proposal to Strengthen Patient-Centred Health Care in Ontario. [Internet]; 2016 June. [cited 2017 Nov 6] Available from: http://www.health.gov.on.ca/en/news/bulletin/2016/docs/patients_first_report_back_20160602.pdf.

15. Ontario Ministry of Health and Long-Term Care. Patients First: One Year Results. [Internet]; 2016 March. [cited 2017 Nov 6] Available from: http://www.health.gov.on.ca/en/ms/ecfa/healthy_change/docs/ year_one_results_action_plan_en.pdf. 